\title{
Nutrient Assimilation by Organisms on Artificial Reefs in a Fish Culture (Example of Hong Kong)
}

\author{
Paul K.S. Shin'1, Qinfeng Gao² and Siu Gin Cheung1 \\ ${ }^{1}$ Department of Biology and Chemistry and State Key Laboratory in Marine Pollution, \\ City University of Hong Kong \\ ${ }^{2}$ College of Fisheries, Ocean University of China,
}

China

\section{Introduction}

An artificial reef (AR) is one or more objects of natural or human origin deposited purposefully onto the seafloor to influence physical, biological or socioeconomic processes related to living marine resources (Seaman \& Jensen, 2000). Traditionally, the most prominent use of ARs has been to mitigate the depletion of fishery stock resulting from over harvest and habitat degradation (Pitcher \& Seaman, 2000). Other purposes of AR deployment include coastline conservation, harbor stabilization, recreational surfing, aquaculture and habitat protection and restoration (Bombace, 1997; Fabi \& Fiorentini 1997; Pickering et al., 1998).

Reef sessile animals, mainly comprising polychaetes, bivalves and gastropods, barnacles, sponges, tunicates and corals can take up and accumulate particles from the surrounding water column through their feeding behavior (Fernández et al., 2004; Gao et al., 2006). During particle capture by reef communities from overlying waters, the metabolic processes of the organisms drive the flux of nutrients between reef-water interfaces. Despite the wellknown capacity of reef communities to take up, ingest and digest particulate matter suspended in the ambient water column (Wotton, 1990; Ribes et al., 1998, 1999), studies on nutrient budgets of faunal organisms in reef communities are scarce (Hearn et al., 2001; Ribes et al., 2003), especially for artificial reefs. Faunal recruitment generally differs between natural and artificial reefs, due to the modifications of the physical environment which result from the reef structure, as well as the settlement preference of the organisms to various substratum materials (Glasby \& Connell, 1999; Smith \& Rule, 2002). As a result, community feeding and physiological processes do not show the necessary consistency between artificial and natural reefs, even for very small temporal and/or spatial scales. Heterogeneous assemblages of epifaunal organisms create a wide range of microcosms and, subsequently, modified physiological processes that cannot be simulated in studies with individual organisms (Sebens et al., 1996). Functional processes of artificial reef communities and concurring nutrient budgets in ecosystems are rarely documented despite numerous reports on the colonization and succession of AR epifauna to mimic the natural community structure (reviewed by Svane \& Petersen, 2001). 
In fish culture zones (FCZ), the foraging of enhanced faunal biomass through the deliberate, calculated installment of AR systems can function as biofilters to reduce organic pollutants from fish rafts. Numerous studies have shown that the rapidly expanding industry of marine fish farming over the last decades has resulted in nutrient and organic enrichment, owing to the release of organic and inorganic waste from uneaten food, feces and dissolved excretory products (see $\mathrm{Wu}, 1995$; Pearson \& Black, 2001; Islam, 2005 for review). In trout farms, for example, only $19-28 \%$ of the total nitrogen $(\mathrm{N})$ supply could be harvested as the end-product of commercial fish (Foy \& Rosell, 1991; Hall et al., 1992). A recent study (Tsutsumi et al., 2006) using sediment traps reported that annual mean organic fluxes to the sea floor from fish rafts were $2.11 \mathrm{~g} \mathrm{C} \mathrm{m}^{-2} \mathrm{~d}^{-1}$ in total organic carbon (TOC) and $0.26 \mathrm{~g} \mathrm{~N} \mathrm{~m}^{-2}$ $\mathrm{d}^{-1}$ in total nitrogen (TN), 2.5 and 2.2 times higher for TOC and TN fluxes, respectively, than those for natural organic flux outside the fish farm. The conceptual model developed by Islam (2005), based on the published data, showed that $132.5 \mathrm{~kg}$ nitrogen and $80.0 \mathrm{~kg}$ phosphorus $(\mathrm{P})$ are released into the environment for each ton of fish production and the annual global $\mathrm{N}$ and $\mathrm{P}$ releases from cage fish culture are 1,325 - 1,387.5 tons and $240.0-$ 250.0 tons, respectively.

In the subtropical waters of Hong Kong, Leung et al. (1999) reported that only $8.6 \%$ of the total $\mathrm{N}$ input to the fish cages was harvested in the form of fish in areolated grouper Epinephelus areolatus. Gao et al. (2005) conducted a one-year study which investigated the effects of nutrient release from fish farming in Hong Kong. Their results showed that, on average, total organic carbon, total Kjeldahl nitrogen and total phosphorus levels of the sediment just beneath the fish cages were 82.8, 128.5 and $1315.7 \%$, respectively; this was higher compared to those of the control seabed areas, which were far away from the fish cages, without the effects of farming activities. The elevated nutrient levels derived from the farming activities stimulate the occurrence of nuisance and toxic algal blooms. The final decay of excess plant production consumes considerable dissolved oxygen, leading to the mass mortality of the cultured fish $(\mathrm{Wu}, 1995)$. As a result of the changes in environmental conditions due to the impacts of farming waste, subsequent alterations in infaunal (Gao et al., 2005) and epifaunal (Cook et al., 2006; Sarà et al., 2007) community structures occurred in the fish culture, as well as in the adjacent waters.

In Hong Kong, cage culture has been widely practiced for the rearing of high-priced carnivorous fishes such as grouper Epinephelus awoara, snapper Lutjanus russellii and seabream Acanthopagrus latus. Unlike the conventional land-based culture of carp, tilapia and milkfish, cage farming of carnivorous species in the open system requires a large amount of high-protein trash fish, e.g., pilchards and anchovies, as feed. The relatively higher food conversion rate (FCR) of trash fish feed (Leung et al., 1999; Pearson \& Black 2001), and the inevitable direct effluent of farming waste to the farming waters, have raised the concern of the adverse impacts of cage aquaculture on open and coastal waters, as well as on the culture farms themselves.

Deployment of ARs, especially in the soft-bottom subtidal zone where hard substrata are unavailable, can provide additional habitats to fulfill species life-history requirements, and eventually increase faunal assemblages. The increased animal assemblages on AR complexes can enhance the environmental cleansing capacity, due to elevated particle removal efficiency by the epibionts, leading to improved environmental conditions (Antsulevich, 1994). Use of filter-feeding organisms on ARs as biofilters has been proven to be one of the more efficient measures in removing farming waste in the fish culture zone 
without contributing to secondary pollution. Angel et al. (2002), for example, reported that the loading of planktonic microalgae, in terms of chlorophyll concentration, was reduced to a level 15-35\% lower than the ambient concentrations when farming water traversed the artificial reefs which were deployed under finfish cages.

The removal efficiency of nutrients, either in FCZ or under natural (non-human impact) conditions, by epifaunal communities, on either natural or artificial reefs, has not been quantified in Hong Kong or anywhere else in the world to date. In the present study, sessile organisms on ARs, which were deployed at the Kau Sai fish culture zone in Hong Kong, were collected on a bimonthly basis, and their nutrient acquisitions and expenditures, including feeding, absorption, carbon respiration and nitrogen and phosphorus excretion, were determined so that the efficiency of nutrient removal by AR epifaunal organisms could be quantified.

\section{Materials and methods}

\subsection{Experimental site and AR design}

The study area is a marine fish culture zone located in Kau Sai Bay, which is a semi-enclosed embayment in the eastern waters of Hong Kong $\left(22^{\circ} 21^{\prime} \mathrm{N}\right.$ and $\left.114^{\circ} 19^{\prime} \mathrm{E}\right)$. The fish raft area, which is confined within the inner part of the bay, is approximately 4.6 ha with water depth ranging from 11-16 m. Each fish cage is approximately $4 \mathrm{~m} \times 4 \mathrm{~m} \times 4 \mathrm{~m}$. The total fish stock is $\sim 500 \mathrm{t}$ with an average density of $4.5 \mathrm{~kg} \mathrm{~m}^{-3}$. The cultured species are mainly grouper (Epinephelus awoara), snapper (Lutjanus russellii) and seabream (Acanthopagrus latus). Small trash fish (mainly anchovies, Thryssa spp.) are used as fish feed. The daily feed supply is $3-5 \%$ of total stock, i.e., $15-25 \mathrm{t} \mathrm{d}^{-1}$.

In April 2002, 16 AR sets made of cement concrete, with dimensions of $3 \mathrm{~m}$ (length) $\times 3 \mathrm{~m}$ (width) $\times 4 \mathrm{~m}$ (height) and total surface area of $250 \mathrm{~m}^{2}$, were deployed around the fish culture zone boundary in Kau Sai Bay. Twelve removable settlement plates were fixed on two sides of each AR for future sampling.

\subsection{Sample collection and preparation}

From August 2003, about one year after the AR deployment, AR plates were collected by SCUBA divers at bimonthly intervals. For each field cruise, five pieces of the removable settlement plates were randomly selected and retrieved. To reduce the bias from to the effects of water depth on the development of epifaunal communities on the ARs, all plates were collected from water depths between 10-13 m. On board the vessel, each plate was labeled individually and placed in a plastic tray. After field retrieval, the sampled AR plates were delivered to the laboratory. The plates were cut into small pieces and washed with seawater to remove excess mud. After the laboratory treatment, the AR plates were transported back to Kau Sai FCZ immediately and cultured in situ in water depths of 10-13 m by hanging them on a fish raft for at least 24 hours prior to biofiltration determination so that the AR organisms would recover to their original status before sample collection and treatment.

\subsection{Determination of feeding processes of epifaunal organisms}

Five replicates of AR plates, approximately $200 \mathrm{~cm}^{2}$, were separately cultured in static flow systems as described by Smaal \& Widdows (1994) at the FCZ (Fig. 1). An extra AR plate of 
similar area (control plate), which has been defaunated by means of refrigeration at $-20{ }^{\circ} \mathrm{C}$ for 48 hours, was placed in an additional culture setup as a control.

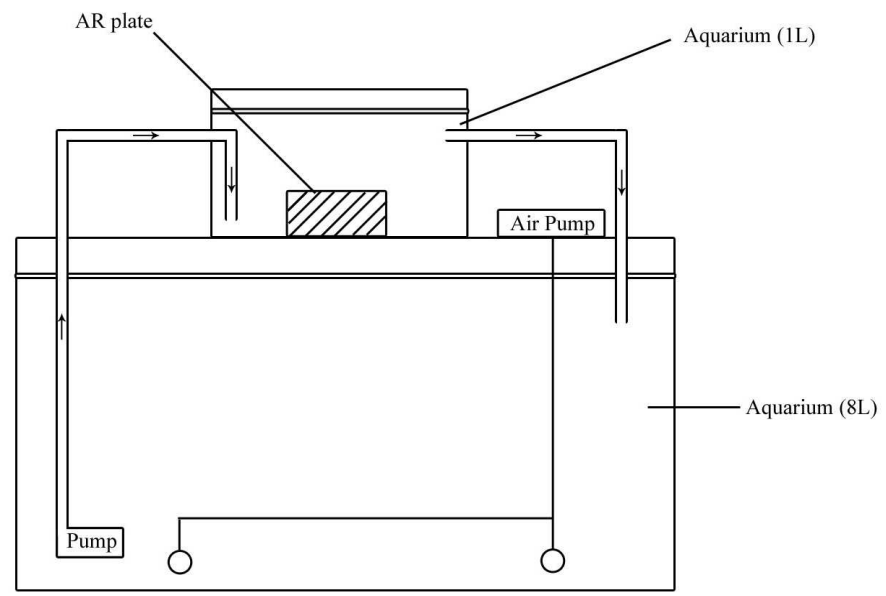

Fig. 1. A water-circulating static system used to determine the clearance rate of the epifaunal organisms on AR plates (adopted from Smaal \& Widdows, 1994).

The AR plates were cultured for one to three hours, depending on the biomass on the plates and the production of fecal pellets, with seawater pumped from the 10-13 m water layer. The experimental time was adjusted so that the maximum reduction in particle concentration was 30\% (Smaal \& Vonck, 1997; Wong \& Cheung, 2001). After cultivation, three replicates of $500 \mathrm{ml}$ water samples and all produced fecal pellets were collected from the six sets of systems and filtered through pre-weighed ashless $47 \mathrm{~mm}$ GF/C filters and rinsed with double distilled deionized water to remove salt adsorbed on the surface of particles or filter paper. The filter papers were dried in an oven at $60^{\circ} \mathrm{C}$ and weighed to the nearest $0.1 \mathrm{mg}$. The concentration of total particulate matter (TPM: $\mathrm{mg} \mathrm{l}^{-1}$ ) for each water sample was measured and fecal egestion rate (ER: $\left.\mathrm{mg} \mathrm{h}^{-1}\right)$ was calculated with the equation:

$$
\mathrm{ER}=\mathrm{DW}_{\mathrm{fp}} / t
$$

where $\mathrm{DW}_{\mathrm{fp}}$ is the dry weight of the produced fecal pellets for each AR plate and $t$ is the culture time. Fecal samples were kept frozen at $-80{ }^{\circ} \mathrm{C}$ for future organic carbon, nitrogen and phosphorus analyses (see below for details).

Clearance rate $\left(\mathrm{CR}: \mathrm{l} \mathrm{h}^{-1}\right)$ is defined as the volume of water cleared per unit time and calculated following the exponential decrease of the seston concentration with the equation (Coughlan, 1969; Karlsson et al., 2003):

$$
\mathrm{CR}=V / t \ln \left(C_{0} / C_{t}\right)
$$

where $V=$ water volume in the experimental aquarium, $t=$ time that the experiment lasted, and $C_{0}$ and $C t=$ seston concentrations in the control aquarium (representing the initial seston concentration) and AR aquarium (representing the final seston concentration), respectively. Filtration rate (FR: $\mathrm{mg} \mathrm{h}^{-1}$ ) is defined as the food mass filtered by the AR epibiota per unit time and computed as the CR times particle concentration in weight unit (Hawkins et al., 
1998). The absorption rate (ABR: $\mathrm{mg} \mathrm{h}^{-1}$ ), representing the food content that was retained in the digestive gut after egestion, was calculated as FR-ER.

\subsection{Determinations of oxygen consumption and nutrient excretion}

To determine oxygen consumption $\left(\mathrm{V}_{\mathrm{O} 2}: \mu \mathrm{g} \mathrm{O} \mathrm{h} \mathrm{h}^{-1}\right)$, each of the experimental and control plates was placed in a separate sealed $800 \mathrm{ml}$ glass chamber. The sealed chambers were fully filled with seawater pumped from the $10-13 \mathrm{~m}$ water column and bathed in a plastic tank supplied with seawater which was continuously pumped from the same water depth to reduce the effects of temperature fluctuations on the respiratory activities of the animals. After 30-60 minutes, depending on the area occupied by the organisms, the DO level of the chambers was measured with a YSI DO meter. $\mathrm{V}_{\mathrm{O} 2}$ was calculated with the equation:

$$
\mathrm{V}_{\mathrm{O} 2}=\left(\mathrm{DO}_{\mathrm{c}}-\mathrm{DO}_{\mathrm{e}}\right) \times V / t
$$

where $\mathrm{DO}_{\mathrm{c}}$ and $\mathrm{DO}_{\mathrm{e}}$ are the $\mathrm{DO}$ levels of control and experimental chambers, respectively, representing initial and final DO levels, $V$ the volume of chamber and $t$ the test time.

To test the ammonium $\left(\mathrm{V}_{\mathrm{N}}: \mu \mathrm{g} \mathrm{N} \mathrm{h}^{-1}\right)$ and phosphate $\left(\mathrm{V}_{\mathrm{P}}: \mu \mathrm{g} \mathrm{P} \mathrm{h}^{-1}\right)$ excretion rates, experimental and control AR plates were maintained in separate glass beakers filled with $750 \mathrm{ml}$ seawater for 30 to 60 minutes. Water samples collected from the experimental and control beakers were stored in an icebox and taken back to the laboratory for nitrogen and phosphorus determination. Ammonium-nitrogen and phosphate-phosphorus concentrations of the seawater samples were colorimetrically determined using the phenolhypochlorite and phospho-molybdate methods, respectively, with a Flow Injection Analyzer (FIA, Lachat, QuikChem 8000) (Strickland \& Parsons, 1977). $V_{N}$ and $V_{P}$ were calculated with an equation similar to that used for the oxygen consumption test.

\subsection{Seston and faeces analysis}

Triplicate 1-litre seawater samples were filtered on pre-combusted and weighed glass-fiber filters and dried at $60^{\circ} \mathrm{C}$ to the nearest $0.1 \mathrm{mg}$, then combusted in a muffle furnace at $450^{\circ} \mathrm{C}$ for six hours and reweighed to determine the total particulate matter (TPM: $\mathrm{mg} \mathrm{l}^{-1}$ ), particulate organic matter (POM: $\mathrm{mg} \mathrm{l}^{-1}$ ), particulate inorganic matter (PIM: $\mathrm{mg} \mathrm{l}^{-1}$ ) and organic content $(f=\mathrm{POM} / \mathrm{TPM})$. Another aliquot of suspended particulate matter on filter paper was dried but not combusted and kept in a freezer at $-80^{\circ} \mathrm{C}$ for future carbon, nitrogen and phosphorus measurements. Particulate organic carbon (POC: $\mu g \mathrm{mg}^{-1}$ ) and particulate organic nitrogen (PON: $\mu \mathrm{g} \mathrm{mg}^{-1}$ ) of seston and faecal pellets on filter papers were measured with a CHNS/O Analyzer (PerkinElmer, PE2400 Series II) (Ribes et al., 2003). For POC measurement, carbonates were removed by fuming the seston on the filters over concentrated $\mathrm{HCl}(37 \%)$ for three days. Samples were then re-dried and re-weighed. The percentage of carbon was corrected for the weight change due to carbonate removal (Kristensen \& Andersen, 1987). Particulate organic phosphorus (POP) was determined following the wet digestion method. The filters retaining a known weight of suspended particulate matter or faecal pellet samples were digested with concentrated sulfuric acid using a digestion block at $200^{\circ} \mathrm{C}$ for 30 minutes for the digestion of detritus and $370^{\circ} \mathrm{C}$ for two hours for the digestion of other phosphorus-containing constituents. Copper sulphate $\left(\mathrm{CuSO}_{4}\right)$ was used as a catalyst and potassium sulfate $\left(\mathrm{K}_{2} \mathrm{SO}_{4}\right)$ was added to raise the boiling point of the digesting acid. The concentrations of total phosphate were determined with a Flow Injection Analyzer (Lachat, QuikChem 8000). 


\subsection{Nutrient element assimilation}

The assimilation rates of the nutrient elements ( $\mathrm{C}, \mathrm{N}$ and $\mathrm{P}$ ) were measured as scope for growth (SFG: $\mu \mathrm{g} \mathrm{h} \mathrm{h}^{-1}$ ) for each element, which is defined as the difference between acquisition and expenditure (Warren \& Davis, 1967; Smaal \& Widdows, 1994). SFG of C, N or P might be calculated as:

$$
\text { SFG }\left(\mu \mathrm{g} \mathrm{h}^{-1}\right)=\mathrm{ABR}-\text { Respiration or Excretion }
$$

Oxygen consumption was converted to $C$ excretion based on a mean respiratory quotient (the ratio between carbon dioxide formed and oxygen used) of 0.85:1 $\mu \mathrm{g} \mathrm{O} \mathrm{O}_{2} \equiv 0.32 \mu \mathrm{g} \mathrm{C}$. For C, excretion is zero, while for $\mathrm{N}$ and $\mathrm{P}$, respiration is zero (Hawkins \& Bayne, 1985; Smaal \& Vonck, 1997). The assimilation of the nutrients by the organisms during each bimonthly test interval was estimated as:

$$
\text { Assimilation }(\mathrm{g})=\left[\mathrm{SFG}\left(\mu \mathrm{g} \mathrm{h}{ }^{-1}\right) \times 24 \mathrm{hs} \times 60 \mathrm{~d}\right] / 10^{6}
$$

Water conditions, including temperature, salinity and DO level, during the field experiments were measured every day. Since water stratification frequently occurs in semi-enclosed Kau Sai FCZ in summer, due to the heating of surface water and weak water movement the temperature, salinity and DO levels in August were measured for each $1 \mathrm{~m}$ of water layer (Gao et al., 2007).

\subsection{Measurement of colonization of epifaunal organisms}

After field biofiltration determination, the AR pieces were preserved in 5\% borax-buffered formalin for measurements of the coverage area by the epifaunal organisms following the methods of Nelson et al. (1994). The area of the AR plate surface which was covered as a projection of the total individuals of each species was measured with a $10 \times 10 \mathrm{~cm}^{2}$ transparent plastic board, of which the surface was evenly divided into $0.5 \times 0.5 \mathrm{~cm}^{2}$ grids. Since the filtration efficiency of animals is proportional to their biomass, the fouling organisms were removed carefully from the AR plates with a cutter, and the wet biomass was weighed to the nearest $0.1 \mathrm{mg}$ with an electronic balance after blotting away the surface water on filter paper.

\subsection{Data analysis}

The relationships of physiological processes of AR epifauna, including feeding, respiration, nitrogen and phosphorus excretion, to wet biomass were analyzed with linear regression. Once the regressive relationships between physiological parameters and biomass were statistically significant (significance level $p<0.05$ ), the physiological parameters were standardized to the equivalent values of $1 \mathrm{~g}$ biomass. Regression analyses were applied to reveal how environmental factors, such as food conditions, temperature, DO level and salinity, affected the physiological processes by simple linear or nonlinear procedures, depending on the most appropriate function to be fitted in each case (Zar, 1999). Multiple regression analysis was conducted when physiological parameters were correlated with more than one environmental condition, and the collinearity between the independents was tested using the collinearity statistics of SPSS (Belsley et al., 2004). Highly correlated independents were eliminated from the independent list and the model was reconstructed until all the intercorrelation between the independent variables was removed from the regressive model. Residuals were also analyzed to check normality and constant variance. Data were transformed, if necessary, to meet the requirements of data normality and homogeneity of variances. All statistical procedures were performed with the SPSS software for Windows, Release 14.0. 


\section{Results}

\subsection{Hydrography, food conditions and nutrient contents}

Bimonthly changes in the bottom hydrographic parameters at the experimental site, such as temperature $(\mathrm{T})$, dissolved oxygen (DO), salinity $(\mathrm{S})$ and food conditions (in terms of total particulate matter (TPM), particulate organic matter (POM), particulate inorganic matter (PIM) and organic content $(f)$ and nutrient contents, including POC, PON and POP of the suspended particulate matter) have been reported in Gao et al. (2007). In brief, water stratification, with a thermocline and a halocline recorded at 4-10 m, occurred in August and exerted considerable effects on bottom conditions. The bottom temperature underwent seasonal variations with high values $\left(\sim 26^{\circ} \mathrm{C}\right)$ in October, decreasing gradually to the lowest $\left(\sim 15^{\circ} \mathrm{C}\right)$ in February. Bottom temperatures during the summer (August) were even lower than in October because of the stratification, despite August having the highest surface value $\left(\sim 31^{\circ} \mathrm{C}\right)$. Bottom DO levels were quite constant over the study period $\left(5.7-7.2 \mathrm{mg} \mathrm{l}^{1-1}\right)$ except the extremely low level of $1.7 \mathrm{mg} \mathrm{l}^{-1}$ in August due to the presence of stratification in summer. Bottom salinity ranged from $\sim 30-33$ PSU throughout the year. Mean TPM and PIM concentrations in winter (TPM 12.62-15.15 $\mathrm{mg} \mathrm{l}^{-1}$; PIM 7.65-11.29 $\mathrm{mg} \mathrm{l}^{-1}$ ) were higher than in summer (TPM 10.16-10.68 $\mathrm{mg} \mathrm{l}^{-1}$; PIM 4.51-5.75 $\mathrm{mg} \mathrm{l}^{-1}$ ) due to the wave-driven resuspension of sediment from the seabed, leading to $f$ values $(0.25-0.39 \%)$ in winter (December to February) relative to those in June and August (0.43-0.58\%). Mean POM, POC and PON showed higher values during the warmer months (POM 4.41-6.17 $\mathrm{mg} \mathrm{l}^{-1}$; POC 129.73-135.56 $\mu_{\mathrm{g} \mathrm{l}}{ }^{-1}$; PON 22.04-24.56 $\mu \mathrm{g} \mathrm{l}^{-1}$ ) and lower values in colder months (POM 3.18$4.97 \mathrm{mg} \mathrm{l}^{-1}$; POC 70.33-81.64 $\mathrm{g} \mathrm{g} \mathrm{l}^{-1}$; PON 11.25-15.60 $\mathrm{g} \mathrm{g} \mathrm{l}^{-1}$ ). A seasonal pattern of fluctuations in POP levels (1.56-2.29 $\left.\mathrm{g} \mathrm{g} \mathrm{l}^{-1}\right)$ was not obvious.

\subsection{Colonization and succession of AR epifauna}

Variations in coverage area and biomass of the epifaunal organisms on the AR plates during the biofiltration measurements from August 2003 to June 2004 are illustrated in Fig. 2. Coverage area by epifaunal organisms on AR plates gradually dropped to the lowest value (mean 19\%) from August to October, owing to the adverse bottom conditions during the summer season. The epibiota, however, resumed recolonization on the ARs after the summer, and the coverage area and biomass peaked in April 2004 (mean 43\%) due to the settlement of juvenile organisms after reproduction in the spring. High mortality of the juveniles after settlement resulted in a reduction in coverage area and biomass of the AR plates sampled in late spring (June). This could be verified through direct observations of a considerable number of empty shells, especially the barnacle Balanus trigonus, on the plates in June 2004. The barnacle Balanus trigonus, the bivalve Pseudochama retroversa and the tunicate Styela species were continuously dominant during the experimental period. Other relatively dominant species included bivalves Bentharca sp. and Dendostrea folium, polychaete Spirobranchus tetraceros, bryozoans Rhynchozoon paratridenticulata, Schizoporella erratoidea and coral Heterocyathus japonicus. Other polychaete tubeworms such as Hydriodes sp. frequently occurred, but never dominantly occupied the AR surface.

\subsection{Feeding of epifaunal organisms}

As illustrated in Fig. 3, feeding processes of epifaunal communities on AR plates, in terms of clearance rate (CR: $\left.\mathrm{mg} \mathrm{l}^{-1} \mathrm{~m}^{-2}\right)$, filtration rate (FR: $\left.\mathrm{mg} \mathrm{h}^{-1} \mathrm{~m}^{-2}\right)$, egestion rate $\left(E R: \mathrm{mg} \mathrm{h}^{-1} \mathrm{~m}^{-2}\right)$ 
and absorption rate (ABR: $\mathrm{mg} \mathrm{h}^{-1} \mathrm{~m}^{-2}$ ) of each $\mathrm{m}^{2} \mathrm{AR}$ plate, were linearly proportional to their biomass (BM: $\mathrm{g} \mathrm{m}^{-2}$ ) according to following equations:

$$
\begin{gathered}
\mathrm{CR}=18.41+20.24 \times \mathrm{BM}\left(r^{2}=0.91, t_{28}=17.05, p<0.01\right) \\
\mathrm{FR}=334.85+233.17 \times \mathrm{BM}\left(r^{2}=0.84, t_{28}=12.32, p<0.01\right) \\
\mathrm{ER}=246.55+134.57 \times \mathrm{BM}\left(r^{2}=0.76, t_{28}=9.41, p<0.01\right) \\
\mathrm{ABR}=88.30+98.60 \times \mathrm{BM}\left(r^{2}=0.69, t_{28}=7.97, p<0.01\right)
\end{gathered}
$$

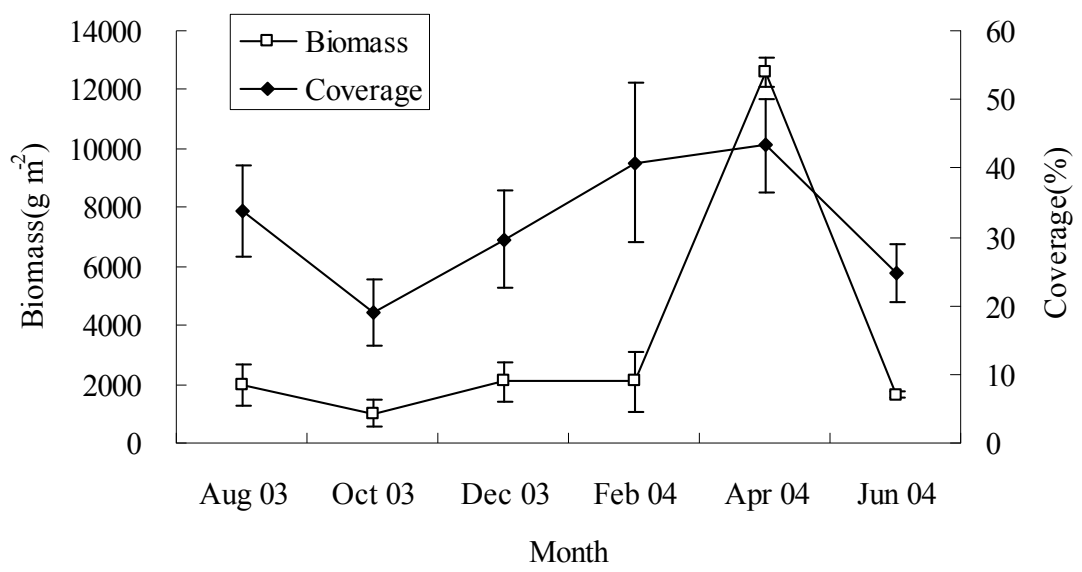

Fig. 2. Bimonthly variations in the communities of AR epifanual organisms in terms of biomass $\left(\mathrm{g} \mathrm{m}^{-2}\right)$ and coverage area (\%) during the biofiltration measurements from August 2003 to June 2004 (values were presented as mean $\pm 1 S D, n=5$ ) (from Shin et al., 2011).

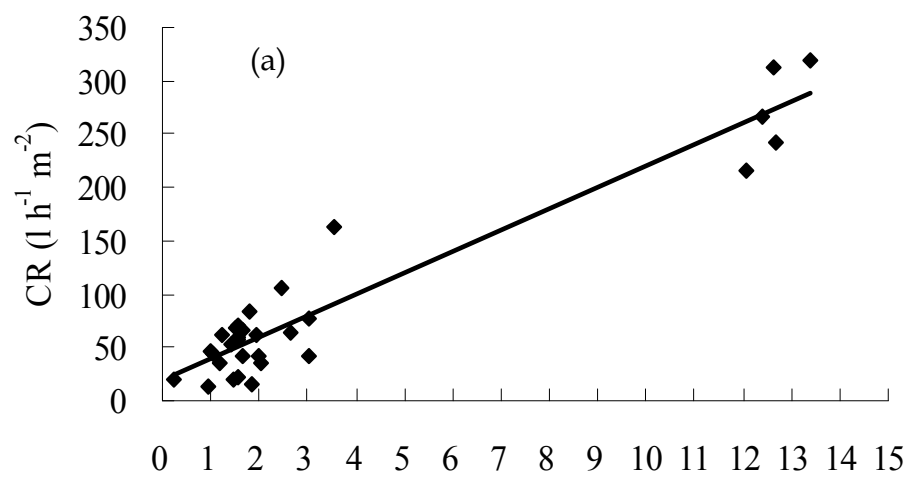

$\mathrm{BM}\left(\times 10^{3} \mathrm{~g}\right)$ 

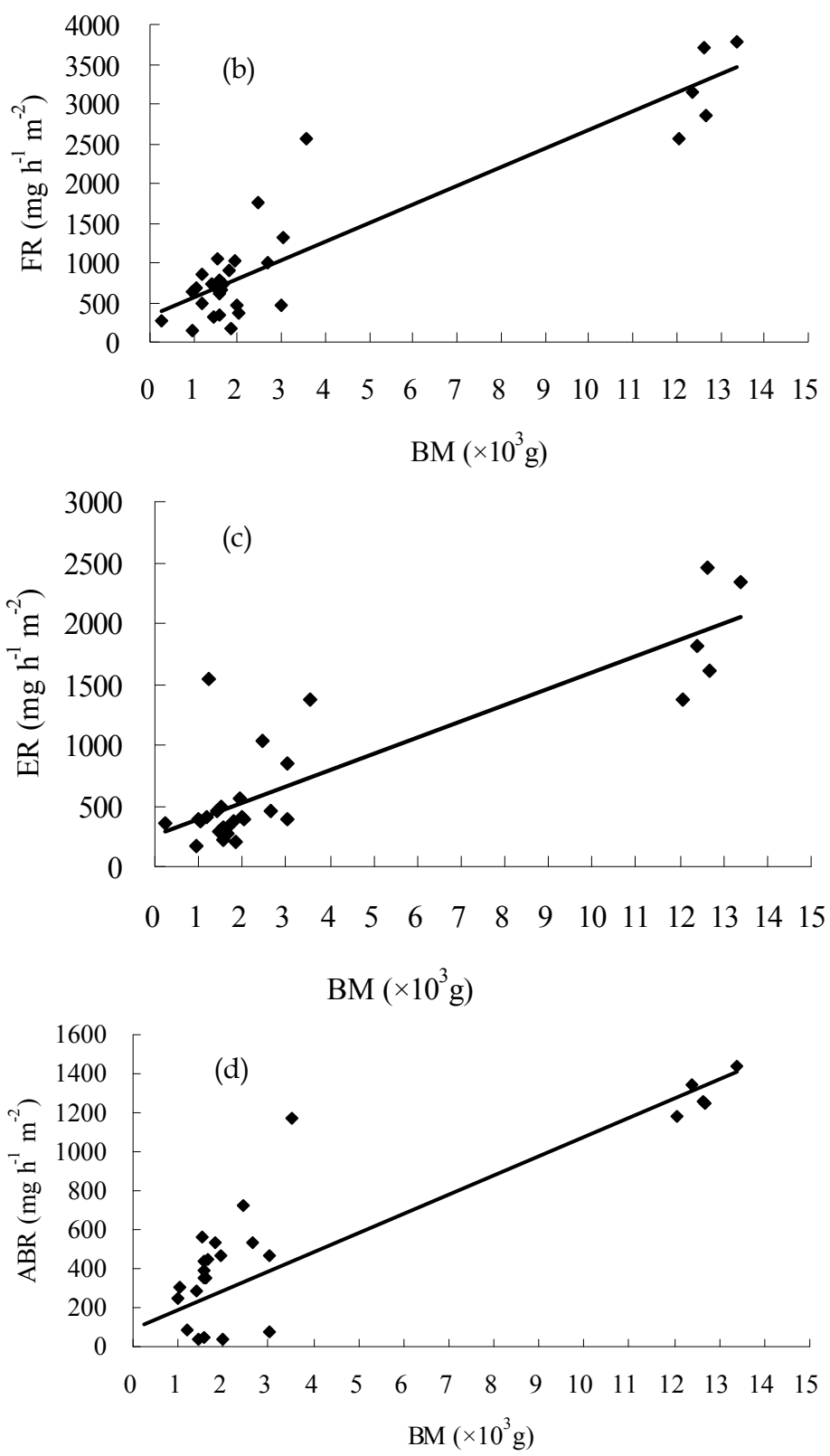

Fig. 3. Relationships of (a) clearance rate (CR: $\left.1 \mathrm{~h}^{-1} \mathrm{~m}^{-2}\right)$, (b) filtration rate (FR: $\mathrm{mg} \mathrm{h}^{-1} \mathrm{~m}^{-2}$ ), (c) egestion rate (ER: $\mathrm{mg} \mathrm{h}^{-1} \mathrm{~m}^{-2}$ ) and (d) absorption rate (ABR: $\mathrm{mg} \mathrm{h}^{-1} \mathrm{~m}^{-2}$ ) of epifaunal organisms on AR plates to their biomass (BM: $\mathrm{g} \mathrm{m}^{-2}$ ) (from Shin et al., 2011). 
The standardized CR (SCR), FR (SFR), ER (SER) and ABR (SABR) of $1 \mathrm{~g}$ biomass (wet weight) for each month, which were calculated based on the linearly proportional relationships between the feeding processes and biomass, are summarized in Table 1 . The relationship of SCRs to the fluctuations in TPM is shown in Fig. 4. At the start, SCR increased with increasing TPM and achieved a peak mean value of $\sim 0.061 \mathrm{~h}^{-1}$ when TPM had an intermediary value of $\sim 14 \mathrm{mg} \mathrm{l}^{-1}$ in October 2003. After this peak value, SCR gradually decreased with increasing TPM. The relationship of SCR to TPM could be described as the quadratic polynomial equation,

$$
\mathrm{SCR}=-0.36+0.059 \times \mathrm{TPM}-0.0021 \times \mathrm{TPM}^{2}\left(r^{2}=0.22, F_{2,26}=2.73, p<0.05\right)
$$

\begin{tabular}{lllll}
\hline Month & $\begin{array}{l}\text { SCR } \\
\left(\mathrm{h} \mathrm{h}^{-1} \mathrm{~g}^{-1}\right)\end{array}$ & $\begin{array}{l}\text { SFR } \\
\left(\mathrm{mg} \mathrm{h}^{-1} \mathrm{~g}^{-1}\right)\end{array}$ & $\begin{array}{l}\text { SER } \\
\left(\mathrm{mg} \mathrm{h}^{-1} \mathrm{~g}^{-1}\right)\end{array}$ & $\begin{array}{l}\text { SABR } \\
\left(\mathrm{mg} \mathrm{h}^{-1} \mathrm{~g}-1\right)\end{array}$ \\
\hline Aug 03 & $0.015 \pm 0.0047$ & $0.14 \pm 0.051$ & $0.13 \pm 0.042$ & $0.010 \pm 0.021$ \\
Oct 03 & $0.055 \pm 0.021$ & $0.67 \pm 0.29$ & $0.62 \pm 0.52$ & $0.049 \pm 0.026$ \\
Dec 03 & $0.025 \pm 0.013$ & $0.55 \pm 0.21$ & $0.40 \pm 0.095$ & $0.15 \pm 0.081$ \\
Feb 04 & $0.036 \pm 0.011$ & $0.63 \pm 0.16$ & $0.35 \pm 0.097$ & $0.28 \pm 0.073$ \\
Apr 04 & $0.021 \pm 0.003$ & $0.25 \pm 0.035$ & $0.15 \pm 0.033$ & $0.10 \pm 0.0053$ \\
Jun 04 & $0.041 \pm 0.0046$ & $0.44 \pm 0.050$ & $0.18 \pm 0.029$ & $0.26 \pm 0.027$ \\
\hline
\end{tabular}

Table 1. The standardized clearance rate (SCR: $\left.1 \mathrm{~h}^{-1} \mathrm{~g}^{-1}\right)$, filtration rate (SFR: $\mathrm{mg} \mathrm{h}^{-1} \mathrm{~g}^{-1}$ ), egestion rate (SER: $\mathrm{mg} \mathrm{h}^{-1} \mathrm{~g}^{-1}$ ) and absorption rate (SABR: $\mathrm{mg} \mathrm{h}^{-1} \mathrm{~g}^{-1}$ ) of $1 \mathrm{~g}^{\text {biomass (wet }}$ weight) of epifaunal organisms on ARs for each bimonthly determination (mean $\pm 1 S D$, $n=5$ ) (from Shin et al., 2011).

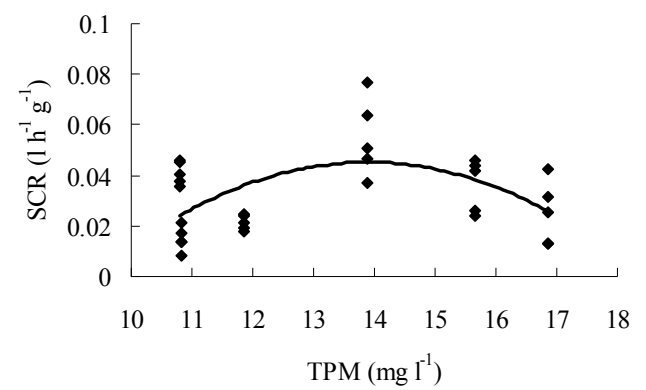

Fig. 4. Relationship of standardized clearance rate (SCR: $\left.1 \mathrm{~h}^{-1} \mathrm{~g}^{-1}\right)$ to concentration of total particulate matter (TPM: $\mathrm{mg} \mathrm{l}^{-1}$ ) (from Shin et al., 2011).

SFR was independent of any food characteristics throughout the experimental period. If the lowest summer filtration rate in August 2003 is excluded, SFR showed a positive relationship to the food quantity in terms of POM, which could be summarized in the following power equation (Fig. 5),

$$
\mathrm{SFR}=0.028 \times \mathrm{POM}^{1.90}\left(r^{2}=0.38, t_{23}=3.74, p<0.01\right)
$$

In addition to food conditions, SCR, SFR and SABR were significantly correlated with bottom DO levels (for SCR, Pearson correlation coefficient $r=0.48, p<0.01$; for SFR, $r=0.64$, $p<0.01$; for SABR, $r=0.59, p<0.01$ ). The positive relationship of SABR to DO could be expressed as an exponential equation, 


$$
\mathrm{SABR}=0.0083 \times \mathrm{e}^{0.47 \mathrm{DO}}\left(r^{2}=0.57, t_{23}=5.54, p<0.01\right)
$$

Integrating the effects of food conditions and bottom dissolved oxygen levels on the feeding behavior of AR epifaunal communities, relationships of SCR and SFR to food quantity and DO could be described by the following multiple regression equations,

$$
\begin{gathered}
\mathrm{SCR}=-0.37+0.047 \times \mathrm{TPM}-0.0017 \times \mathrm{TPM}^{2}+0.069 \times \mathrm{DO}^{0.16}\left(r^{2}=0.38, F_{5,25}=36.0, p<0.01\right) \\
\mathrm{SFR}=2.61-4.80 \times \mathrm{POM}-0.28+0.31 \times \mathrm{DO}^{0.68}\left(r^{2}=0.62, F_{5,25}=60.7, p<0.01\right)
\end{gathered}
$$

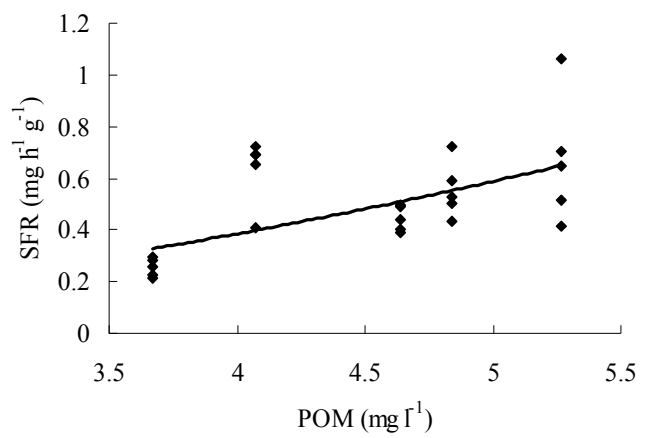

Fig. 5. Relationship of standardized filtration rate (SFR: $\left.\mathrm{mg} \mathrm{h}^{-1} \mathrm{~g}^{-1}\right)$ to particulate organic matter (mg l-1) (from Shin et al., 2011).

\subsection{Nutrient budgets}

Relationships of oxygen consumption rate $\left(\mathrm{V}_{\mathrm{O} 2}: \mathrm{mg} \mathrm{h}^{-1} \mathrm{~m}^{-2}\right)$, nitrogen $\left(\mathrm{V}_{\mathrm{N}}: \mathrm{mg} \mathrm{h}^{-1} \mathrm{~m}^{-2}\right)$ and phosphorus ( $\mathrm{V}_{\mathrm{P}}: \mathrm{mg} \mathrm{h}^{-1} \mathrm{~m}^{-2}$ ) excretion rate to biomass (BM: $\mathrm{g} \mathrm{m}^{-2}$ ) are shown in Fig. 6. $\mathrm{V}_{\mathrm{O} 2 \text {, }}$ $V_{N}$ and $V_{P}$ all showed linear relationships to biomass as following equations:

$$
\begin{gathered}
\mathrm{V}_{\mathrm{O} 2}=-25.46+68.51 \times \mathrm{BM}\left(r^{2}=0.97, t_{28}=31.20, p<0.01\right) \\
\mathrm{V}_{\mathrm{N}}=0.89+1.29 \times \mathrm{BM}\left(r^{2}=0.80, t_{28}=10.63, p<0.01\right) \\
\mathrm{V}_{\mathrm{P}}=-0.27+0.42 \times \mathrm{BM}\left(r^{2}=0.88, t_{28}=14.02, p<0.01\right)
\end{gathered}
$$

\begin{tabular}{lllll}
\hline Month & $\begin{array}{l}\mathrm{SV}_{\mathrm{O} 2} \\
\left(\mu \mathrm{g} \mathrm{h}^{-1} \mathrm{~g}^{-1}\right)\end{array}$ & $\begin{array}{l}\mathrm{SV}_{\mathrm{C}} \\
\left(\mu \mathrm{g} \mathrm{h} \mathrm{g}^{-1}\right)\end{array}$ & $\begin{array}{l}\mathrm{SV}_{\mathrm{N}} \\
\left(\mu \mathrm{g} \mathrm{h} \mathrm{g}^{-1}\right)\end{array}$ & $\begin{array}{l}\mathrm{SV}_{\mathrm{P}} \\
\left(\mu \mathrm{g} \mathrm{h} \mathrm{g} \mathrm{g}^{-1}\right)\end{array}$ \\
\hline Aug 03 & $21.38 \pm 4.99$ & $6.84 \pm 1.60$ & $3.00 \pm 0.99$ & $0.68 \pm 0.17$ \\
Oct 03 & $73.50 \pm 14.40$ & $23.52 \pm 4.61$ & $1.75 \pm 0.57$ & $0.44 \pm 0.15$ \\
Dec 03 & $61.84 \pm 13.06$ & $19.79 \pm 4.18$ & $1.45 \pm 0.20$ & $0.44 \pm 0.13$ \\
Feb 04 & $71.45 \pm 4.57$ & $22.87 \pm 1.46$ & $1.03 \pm 0.13$ & $0.51 \pm 0.21$ \\
Apr 04 & $66.49 \pm 6.12$ & $21.28 \pm 1.96$ & $1.36 \pm 0.37$ & $0.41 \pm 0.57$ \\
Jun 04 & $47.45 \pm 4.22$ & $15.18 \pm 1.36$ & $1.67 \pm 0.45$ & $0.48 \pm 0.28$ \\
\hline
\end{tabular}

Table 2. Standardized rates of oxygen consumption $\left(\mathrm{SV}_{\mathrm{O} 2}: \mu \mathrm{g} \mathrm{h}^{-1} \mathrm{~g}^{-1}\right)$, carbon respiration $\left(\mathrm{SV}_{\mathrm{C}}: \mu \mathrm{g} \mathrm{h} \mathrm{h}^{-1} \mathrm{~g}^{-1}, 1 \mu \mathrm{g} \mathrm{O} \mathrm{O}_{2} \equiv 0.32 \mu \mathrm{g} \mathrm{C}\right.$ ), and excretion of nitrogen (SV $\left.\mathrm{N}_{\mathrm{N}} \mu \mathrm{g} \mathrm{h}^{-1} \mathrm{~g}^{-1}\right)$ and phosphorus $\left(\mathrm{SV}_{\mathrm{P}}: \mu \mathrm{g} \mathrm{h}^{-1} \mathrm{~g}^{-1}\right)$ of $1 \mathrm{~g}$ epifaunal biomass (mean $\left.\pm 1 \mathrm{SD}, n=5\right)$ (from Shin et al., 2011). 
Based on these linear models, the standardized $\mathrm{V}_{\mathrm{O} 2}\left(\mathrm{SV}_{\mathrm{O} 2}: \mu \mathrm{g} \mathrm{h} \mathrm{h}^{-1} \mathrm{~g}^{-1}\right)$, carbon respiration $\left(\mathrm{SV}_{\mathrm{C}}: \mu \mathrm{g} \mathrm{h}^{-1} \mathrm{~g}^{-1}, 1 \mu \mathrm{g} \mathrm{O}_{2} \equiv 0.32 \mu \mathrm{g}\right.$ C), $\mathrm{V}_{\mathrm{N}}\left(\mathrm{SV}_{\mathrm{N}}: \mu \mathrm{g} \mathrm{h} \mathrm{h}^{-1} \mathrm{~g}^{-1}\right)$ and $\mathrm{V}_{\mathrm{P}}\left(\mathrm{SV}_{\mathrm{P}}: \mu \mathrm{g} \mathrm{h} \mathrm{h}^{-1} \mathrm{~g}^{-1}\right)$ of $1 \mathrm{~g}$ biomass are summarized in Table 2. $\mathrm{SV}_{\mathrm{O} 2}$ and $\mathrm{SV}_{\mathrm{C}}$ showed the lowest rates in August 2003. In contrast, $\mathrm{SV}_{\mathrm{N}}$ value in August 2003 was much higher than other months and $\mathrm{SV}_{\mathrm{P}}$ appeared relatively constant throughout the experimental period.
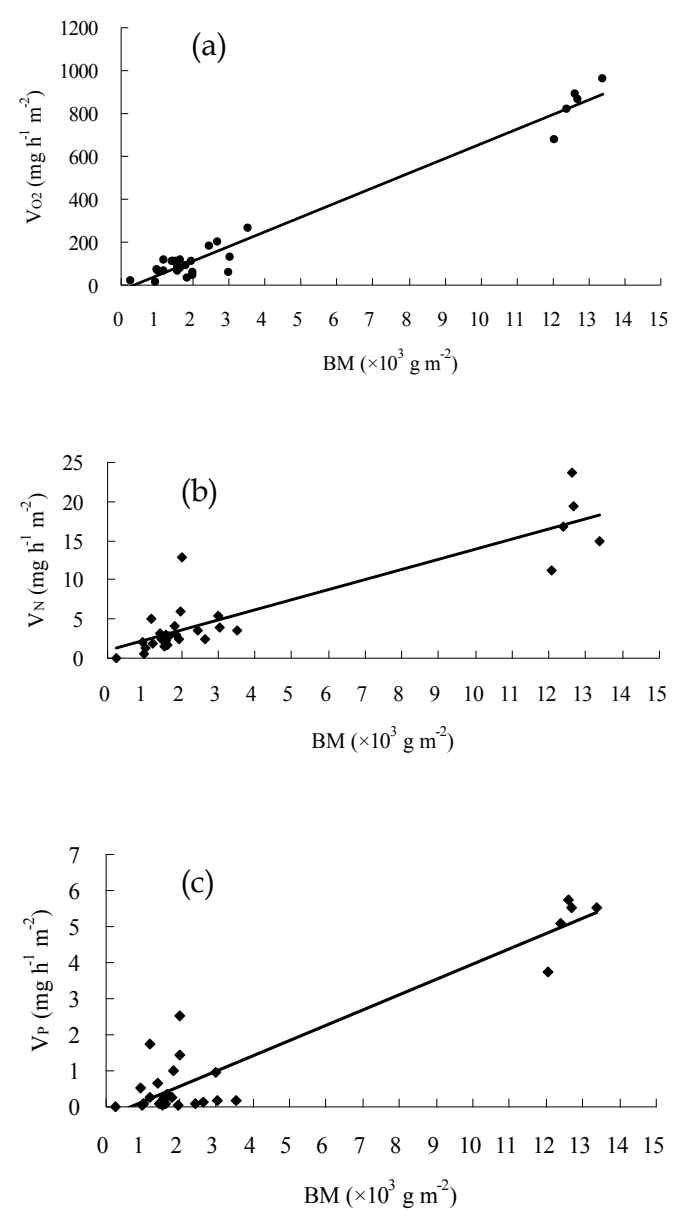

Fig. 6. Relationships of (a) oxygen consumption $\left(\mathrm{V}_{\mathrm{O} 2:} \mathrm{mg} \mathrm{h}^{-1} \mathrm{~m}^{-2}\right)$, (b) excretion rate of nitrogen $\left(\mathrm{V}_{\mathrm{N}}: \mathrm{mg} \mathrm{h}^{-1} \mathrm{~m}^{-2}\right)$ and (c) phosphorus $\left(\mathrm{V}_{\mathrm{P}}: \mathrm{mg} \mathrm{h}^{-1} \mathrm{~m}^{-2}\right)$ to biomass of AR epifaunal organisms (BM: $\mathrm{g} \mathrm{m}^{-2}$ ) (from Shin et al., 2011).

As a result of the balance between nutrient absorption via food uptake and nutrient consumption due to carbon respiration or nitrogen and phosphorus excretion, nutrient budgets in terms of carbon, nitrogen and phosphorus SFGs by $1 \mathrm{~m}^{2} \mathrm{AR}$ plate in October and December of 2003, and February and June of 2004 were positive, indicating that nutrient 
absorption via food uptake was larger than their expenditure due to carbon respiration and nitrogen and phosphorus excretion in these four months. In contrast, nutrient SFGs in August 2003 and April 2004 were negative, showing that AR epifaunal organisms consumed more nutrients than they absorbed in these two months. As a result, the annual mass values of carbon, nitrogen and phosphorus that were assimilated by the epifaunal organisms on each $1 \mathrm{~m}^{2}$ AR plate were $588.12 \mathrm{~g}, 156.06 \mathrm{~g}$, and $25.71 \mathrm{~g}$, respectively (Table 3 ).

\begin{tabular}{lcccccc}
\hline \multirow{2}{*}{ Month } & \multicolumn{3}{c}{ SFG $\left(\mu \mathrm{g} \mathrm{h}^{-1} \mathrm{~m}^{-2}\right)$} & \multicolumn{3}{c}{ Assimilation $\left(\mathrm{g} \mathrm{m}^{-2}\right)$} \\
\cline { 2 - 7 } & $\mathrm{C}$ & $\mathrm{N}$ & $\mathrm{P}$ & $\mathrm{C}$ & $\mathrm{N}$ & $\mathrm{P}$ \\
\hline Aug 03 & $-30022 \pm 7971$ & $-13684 \pm 2043$ & $-1015 \pm 299$ & -43.23 & -19.71 & -1.46 \\
Oct 03 & $58141 \pm 13574$ & $2939 \pm 423$ & $104 \pm 31$ & 83.72 & 4.23 & 0.15 \\
Dec 03 & $43484 \pm 13818$ & $26318 \pm 5846$ & $6000 \pm 865$ & 62.62 & 37.90 & 8.64 \\
Feb 04 & $180821 \pm 54910$ & $63018 \pm 9419$ & $10402 \pm 1426$ & 260.38 & 90.75 & 14.98 \\
Apr 04 & $-145966 \pm 36402$ & $-13258 \pm 1387$ & $-2566 \pm 630$ & -210.19 & -19.08 & -3.70 \\
Jun 04 & $301955 \pm 13392$ & $43036 \pm 7750$ & $4929 \pm 192$ & 434.82 & 61.97 & 7.10 \\
Yearly & & - & - & 588.12 & 156.06 & 25.71 \\
budget & - & - & - & & & \\
\hline
\end{tabular}

Table 3. Bimonthly changes in SFGs and total assimilation of carbon, nitrogen and phosphorus for $1 \mathrm{~m}^{2} \mathrm{AR}$ plate (mean $\pm \mathrm{SD}, n=5$ ) (from Shin et al., 2011).

\section{Discussion}

The findings of this study indicated that artificial reefs (ARs) deployed under fish rafts can function as biofilters to reduce particulate nutrient enrichments in fish culture zone and adjacent waters. This is accomplished via food uptake by the epifaunal organisms on the AR surface, despite the net release of nutrients to the environments in two of the six experimental months (a the result of the metabolic budget between nutrient absorption and consumption).

For nutrient acquisition (feeding and absorption) and expenditure (respiration and excretion), high goodness-of-fit ( $r^{2}$ values) of the regressive models between physiological rates and biomass on unit areas of AR plates revealed that the nutrient removal efficiencies of AR systems were primarily controlled by the changes in community development due to the colonization and succession of epifauna on the AR surface. Community structure of sessile organisms on the surface of hard habitats is controlled by both biotic factors, such as reproductive cycle, larval settlement, growth and life span of each component species and abiotic factors, such as salinity, temperature, $\mathrm{pH}$, dissolved oxygen and the texture of the substratum itself (Moran and Grant, 1993; Kocak \& Kucuksezgin, 2000; Qian et al., 2000). In temperate and subtropical regions such as Hong Kong, most marine organisms show bimodal reproductive cycles peaking in spring and autumn (Morton \& Morton, 1983). The summer bottom hypoxic condition at the study site, caused by the presence of stratification, led to a high number of mortalities in the epibiotic communities from the summer to early autumn months (Gao et al, 2007). After the summer hypoxia, settlement and growth of the epifaunal communities resumed from autumn to late spring, owing to continuous larval recruitment and juvenile and adult growth under such relatively suitable hydrographic conditions. The epifaunal 
communities fully developed in late spring (April), in terms of coverage area, and biomass peaked at this time due to the extensive larval settlement during the spring reproductive stage. The slow growth of epifaunal communities at the beginning of summer (June) could be attributed to termination of larval settlement and collapse of the populations of some dominant species, e.g., barnacles, ascidians and sponges, caused by the high mortality of juvenile individuals that settled in the early spring months.

The standardized feeding rates, i.e., nutrient acquisition efficiencies, of the epifauna for $1 \mathrm{~g}$ biomass were significantly related to the environmental factors, such as TPM, POM and DO level. Numerous research studies revealed that bivalves, ascidians and other filter-feeding species possess regulating functions to optimize energy acquisition in the presence of various seston concentrations and composition (Robbins, 1984; Riisgård, 1988; Petersen \& Riisgård, 1992; Bayne, 1993; Petersen et al., 1995). In the present study, fluctuations in standardized clearance rate (SCR) in response to the changing food quantity, in terms of $\mathrm{TPM}$, indicated the presence of a pre-ingestive regulating mechanism in filter-feeding aquatic organisms (Fig. 4). At the relatively low TPM concentration (< $\left.14 \mathrm{mg} \mathrm{l}^{-1}\right)$, SCR increased with increasing TPM; when TPM was larger than the threshold concentration of $14 \mathrm{mg} \mathrm{l}^{-1}$, SCR showed down-regulating pattern, i.e., decreased with increasing TPM. Generally, the filtration rate of epifauna was elevated in response to increased POM (Fig. 5), as a higher supply of suspended particles increased the opportunity for the epifauna to take up the particulate matter (Ribes et al., 2003).

The concentration of dissolved oxygen is another factor determining the metabolism of aquatic animals (Hummel et al., 2000; Huang \& Newell, 2002). During the experimental period, DO levels underwent considerable fluctuations and significantly affected the metabolism of the component species and, consequently, the entire community structure. The hypoxic conditions $\left(<2 \mathrm{mg} \mathrm{l}^{-1}\right)$ in summer months significantly inhibited feeding, absorption and nutrient consumption by the epifauna. As a result, all standardized metabolic rates of unit epifaunal biomass, including clearance rate, filtration rate, absorption rate, carbon respiration and nitrogen and phosphorus excretion, dropped to the lowest levels under such extremely adverse summer conditions (Table 2). Owing to the adverse effects of hypoxia on nutrient acquisition and consumption of epibiotic organisms, carbon, nitrogen and phosphorus budgets showed negative values, indicating the net expenditure of body reserves under environmental stresses.

Studies on the use of artificial reefs as biofilters to reduce pollution under natural or farming conditions have rarely been reported. Angel et al. (2002) observed that the depletion of the chlorophyll $a$ level might be detected in the water traversing the artificial reefs installed under fish farms compared to that in the upstream water, indicating the absorption of organic matter from fish farms by the organisms on ARs. Bugrov (1994) and Laihonen et al. (1996) also suggested that artificial reef-fish cage complexes may have the potential to remove particulate and dissolved matter from fish farm effluents.

Assimilation of carbon, nitrogen and phosphorus by epifaunal organisms on ARs led to a net accumulation of these nutrients from ambient waters to the biomass, suggesting the bioremediation function of AR epifaunal organisms as biofilters to reduce nutrient pollution from fish farming. By taking the total AR surface area of $250 \mathrm{~m}^{2} \mathrm{AR}^{-1} \times 16$ ARs $=4,000 \mathrm{~m}^{2}$, the total filtration capacity was estimated at $8,736 \mathrm{~m}^{3} \mathrm{~d}^{-1}$, and removal of carbon was 2,352 kg, nitrogen $624 \mathrm{~kg}$ and phosphorus $103 \mathrm{~kg}$ per year, or 6.4, 1.7 and $0.3 \mathrm{~kg} \mathrm{~d}^{-1}$, respectively. According to a local study by Leung et al. (1999), the nitrogen loss 
rate from fish farms to surrounding waters is $321 \mathrm{~kg} \mathrm{~N} \mathrm{t}^{-1}$ fish production. Using this figure, the yearly nitrogen removal by all ARs in the present study is thus equivalent to nitrogen loss from about two tons of fish production. Such filtration capacity and efficiency are clearly beneficial to reducing the excessive nutrients generated from current fish farming practices.

Currently, the greatest limitation for the application of artificial reefs to remove farming waste is the fate of the accumulated nutrients in the forms of biomass on the ARs. To solve this problem, Antsulevich (1994) suggested an improved AR design with removable plates and the facilities for collecting matter which drops from the ARs. With such a specialized design for cleansing waters, the biomass with absorbed nutrients could be harvested conveniently from the farming waters. On the other hand, ARs provide additional habitat and shelter for the pelagic fish. The aggregates of the carnivorous fish thus function as another group of consumers to take up the sessile organisms on the ARs, as well as the farming wastes (Relini et al., 2002).

Studies investigating the exchange of nutrients between various biotic and abiotic compartments in fish farms are also important in a wider biogeochemial context for deciphering the processes of nutrient fluxes in organic-enriched waters. Considering the global issue of the increasing destruction of coastal reef-habitat [from seashore overexploitation (Hilton \& Manning, 1995; Wilkinson, 1998)], this deciphering process may be applicable for a better understanding of the eutrophication in shallow coastal marine ecosystems (Nixon, 1995; Kemp et al., 2005). In the present study, in situ determination of the nutrient assimilation by filter-feeding sessile organisms on artificial reefs showed that faunal communities inhabiting reef systems can efficiently remove eutrophic nutrients from surrounding waters, indicating the important role that reef habitats play during the processes of nutrient dynamics in marine ecosystems.

\section{Acknowledgement}

We would like to thank Harry Chai and Kwok Leung Cheung for their assistance in the field. The work described in this paper was partially funded by a grant from the Hong Kong Research Grants Council (Project No. CityU 1404/06M).

\section{References}

Angel, D.L.; Eden, N.; Breitstein, S.; Yurman, A.; Katz, T. \& Spanier, E. (2002) In situ biofiltration: a means to limit the dispersal of effluents from marine finfish cage aquaculture. Hydrobiologia, Vol.469, pp. 1-10, ISSN 0018-8158

Antsulevich, A.E. (1994) Artificial reefs project for improvement of water quality and environmental enhancement of Neva Bay (ST.-Petersburg County Region). Bulletin of Marine Science, Vol.55, pp. 1189-1192, ISSN 0007-4977

Bayne, B.L. (1993) Feeding physiology of bivalves: time-dependence and compensation for changes in food availability. In: Bivalve Filter Feeders in Estuarine and Coastal Water Eecosystem Processes, R.F. Dame, (Ed.), 1-24, Springer-Verlag, ISBN 978-038756952, Berlin/Heidelberg, Germany 
Belsley, D.A.; Kuh, E. \& Welsch, R.E. (2004) Regression Diagnostics: Identifying Influential Data and Sources of Collinearity. Wiley-Interscience, ISBN 0471691178, New York

Bombace, G. (1997) Protection of Biological Habitats by Artificial Reefs, European Artificial Reef Research: Proceedings of the first EARRN Conference, pp. 1-15, ISBN 0-904175-28-6, Ancona, Italy, March, 1996

Bugrov, L.Y. (1994) Fish-farming and artificial reefs: complex for waster technology. Bulletin of Marine Science, Vol.55, p. 1332, ISSN 0007-4977

Cook, E.J.; Black, K.D.; Sayer, M.D.J; Cromey, C.J.; Angel, D.L.; Spanier, E.; Tsemel, A.; Katz, T. \& Eden, N. (2006) The influence of caged mariculture on the early development of sublittoral fouling: a pan-European study. ICES Journal of Marine Science, Vol.63, pp. 637-649, ISSN 1054-3139

Coughlan, J. (1969) The estimation of filtering rate from the clearance of suspensions. Marine Biology, Vol.2, pp. 356-358, ISSN 0025-3162

Fabi, G. \& Fiorrentini, L. (1997) Molluscan Aquaculture on Reefs, European Artificial Reef Research: Proceedings of the first EARRN Conference, pp. 123-140, ISBN 0-904175-28-6, Ancona, Italy, March, 1996

Fernández, D.; López-Urrutia, Á; Fernández, A; Acuña, J.L. \& Harris, R. (2004) Retention efficiency of 0.2 to $6 \mu \mathrm{m}$ particles by the appendicularians Oikopleura dioica and Fritillaria borealis. Marine Ecology - Progress Series, Vol.266, pp. 89-101, ISSN 01718630

Foy, R.H. \& Rosell, R. (1991) Loadings of nitrogen and phosphorus from a Northern Ireland fish farm. Aquaculture, Vol.96, pp. 17-30, ISSN 0967-6120

Gao, Q.F.; Cheung, K.L.; Cheung, S.G. \& Shin, P.K.S. (2005) Effects of nutrient enrichment derived from fish farming activities on macroinvertebrate assemblages in a subtropical region of Hong Kong. Marine Pollution Bulletin, Vol.51, pp. 994-1002, ISSN 0025-326X

Gao, Q.F.; Shin, P.K.S.; Lin, G.H.; Chen, S.P. \& Cheung, S.G. (2006) Stable isotopic and fatty acid evidence for uptake of organic wastes from fish farming through green-lipped mussels (Perna viridis) in a polyculture system. Marine Ecology - Progress Series, Vol.317, pp. 273-283, ISSN 0171-8630

Gao, Q.F.; Xu, W.Z.; Liu, X.S.; Cheung, S.G. \& Shin, P.K.S. (2008) Seasonal changes in C, N and $\mathrm{P}$ budgets of green-lipped mussels (Perna viridis) and their application as biofilters to remove nutrients from fish farming in Hong Kong. Marine Ecology Progress Series, Vol.353, pp. 137-146, ISSN 0171-8630

Glasby, T.M. \& Connell, S.D. (1999) Urban structures as marine habitats. Ambio, Vol.28, pp. 595-598, ISSN 0301-0325

Hall, P.O.J.; Holby, O.; Kollberg, S. \& Samuelsson, M.O. (1992) Chemical fluxes and mass balances in a marine fish cage farm. IV. Nitrogen. Marine Ecology - Progress Series, Vol.89, pp. 81-91, ISSN 0171-8630

Hawkins, A.J.S. \& Bayne, B.L. (1985) Seasonal variation in the relative utilization of carbon and nitrogen by the mussel Mytilus edulis: budgets, conversion efficiencies and maintenance requirements. Marine Ecology - Progress Series, Vol.25, pp. 181-188, ISSN 0171-8630 
Hawkins, A.J.S.; Bayn, B.L.; Bougrier, S; Héral, M; Iglesias, J.I.P.; Navarro, E.; Smith, R.F.M. \& Urrutia, M.B. (1998) Some general relationships in comparing the feed physiology of suspension-feeding bivalve molluscs. Journal of Experimental and Marine Biology and Ecology, Vol.219, pp. 87-103, ISSN 0022-0981

Hearn, C.J.; Atkinson, M.J. \& Falter, J.L. (2001) A physical derivation of nutrient-uptake rates in coral reefs: effects of roughness and waves. Coral Reefs, Vol.20, pp. 347-356, ISSN 0722-4028

Hilton, M.J. \& Manning, S.S. (1995) Conversion of coastal habitats in Singapore: Indications of unsustainable development. Environmental Conservation, Vol.22, pp. 307-322, ISSN 0376-8929

Huang, S.C. \& Newell, R.I.E. (2002) Seasonal variations in the rates of aquatic and aerial respiration and ammonium excretion of the ribbed mussel, Geukensia demissa (Dillwyn). Journal of Experimental and Marine Biology and Ecology, Vol.270, pp. 241255, ISSN 0022-0981

Hummel, H.; Bogaards, R.H.; Bachelet, G.; Caron, F.; Sola, J.C. \& Amiard-Triquet, C. (2000) The respiratory performance and survival of the bivalve Macoma balthica (L.) at the southern limit of its distribution area: a translocation experiment. Journal of Experimental and Marine Biology and Ecology, Vol.251, pp. 85-102, ISSN 0022-0981

Islam, Md. S. (2005) Nitrogen and phosphorus budget in coastal and marine cage aquaculture and impacts of effluent loading on ecosystem: review and analysis towards model development. Marine Pollution Bulletin, Vol.50, pp. 48-61, ISSN 0025326X

Karlsson, Ö.; Jonsson, P.R. \& Larsson, A.I. (2003) Do large seston particles contribute to the diet of the bivalve Cerastoderma edule? Marine Ecology - Progress Series, Vol.261, pp. 161-173, ISSN 0171-8630

Kemp, W.M. \& other 17 authors (2005) Eutrophication of Chesapeake Bay: historical trends and ecological interactions. Marine Ecology - Progress Series, Vol.303, pp. 1-29, ISSN 0171-8630

Kocak, F. \& Kucuksezgin, F. (2000) Sessile fouling organisms and environmental parameters in the marinas of the Turkish Aegean coast. Indian Journal of Marine Sciences, Vol.29, pp. 149-157, ISSN 0379-513

Kristensen, E. \& Andersen, F.Ø. (1987) Determination of organic carbon in marine sediments: a comparison of two CHN-analyzer methods. Journal of Experimental and Marine Biology and Ecology, Vol.109, pp. 15-23, ISSN 0022-0981

Laihonen, P.; Hännunen, J.; Chojnacki, J. \& Vuorinen, I. (1996) Some Prospects of Nutrient Removal with Artificial Reefs, European Artificial Reef Research: Proceedings of the first EARRN Conference, pp. 85-96, ISBN 0-904175-28-6, Ancona, Italy, March, 1996

Leung, K.M.Y.; Chu, J.C.W. \& Wu, R.S.S. (1999) Nitrogen budgets for the areolated grouper, Epinephelus areolatus, cultured under laboratory conditions and in open-sea cages. Marine Ecology - Progress Series, Vol.186, pp. 271-281, ISSN 0171-8630 
Moran, P.J. \& Grant, T.R. (1993) Larval settlement of marine fouling organisms in polluted water from Port Kembla Harbour, Australia. Marine Pollution Bulletin, Vol.15, pp. 512-514, ISSN 0025-326X

Morton, B. \& Morton, J. (1983) The Sea Shore Ecology of Hong Kong, Hong Kong University Press, ISBN 962-209-027-3, Hong Kong

Nelson, W.G.; Savercool, D.M.; Neth, T.E. \& Rodda, J.R. (1994) A comparison of the fouling community development on stabilized oil-ash and concrete reefs. Bulletin of Marine Science, Vol.55, pp. 1303-1315, ISSN 0007-4977

Nixon, S.W. (1995) Coastal marine eutrophication: A definition, social causes, and future concerns. Ophelia, Vol.41, pp. 199-220, ISSN 0078-5326

Pearson, T.H. \& Black, K.D. (2001) The environmental impacts of marine fish cage culture. In: Environmental Impacts of Aquaculture, K.D. Black, (Ed.), 1-31, Sheffield Academic Press, ISBN 1-84127-041-5, Sheffield, UK

Petersen, J.K. \& Riisgård, H.U. (1992) Filtration capacity of the ascidian Ciona intestinalis and its grazing impact in a shallow fjord. Marine Ecology - Progress Series, Vol.88, pp. 917, ISSN 0171-8630

Petersen, J.K.; Schou, O. \& Thor, P. (1995) Growth and energetics in the ascidian Ciona intestinalis. Marine Ecology - Progress Series, Vol.120, pp. 175-184, ISSN 0171-8630

Pickering, H.; Whitmarsh, D. \& Jensen, A. (1998) Artificial reefs as a tool to aid rehabilitation of coastal ecosystems: Investigating the potential. Marine Pollution Bulletin, Vol.37, pp. 505-514, ISSN 0025-326X

Pitcher, T.J. \& Seaman, W. (2000) Petrarch's principles: How protected human-made reefs can help the reconstruction of fisheries and marine ecosystems. Fish and Fisheries Vol.1, pp. 73-81, ISSN 1467-2979

Qian, P.Y.; Rittschof, D. \& Sreedhar, B. (2000) Macrofouling in unidirectional flow: miniature pipes as experimental models for studying the interaction of flow and surface characteristics on the attachment of barnacle, bryozoan and polychaete larvae. Marine Ecology - Progress Series, Vol.207, pp.109-121, ISSN 0171-8630

Relini, G.; Relini. M.; Rorchia, G. \& De Angelis, G. (2002) Trophic relationships between fishes and an artificial reefs. ICES Journal of Marine Science, Vol.59, pp. S36-S42, ISSN 1054-3139

Ribes M, Coma R, Gili JM (1998) Seasonal variation of in situ feeding rates by the temperate ascidian Halocynthia papillosa. Marine Ecology - Progress Series, Vol.175, pp. 201-213, ISSN 0171-8630

Ribes, M.; Coma, R. \& Gili, J.M. (1999) Natural diet and grazing rate of the temperate sponge Dysidea avara (Demospongia, Dendroceratida) through an annual cycle. Marine Ecology - Progress Series, Vol.176, pp. 179-190, ISSN 0171-8630

Ribes, M.; Coma, R. Atkinson, M.J. \& Kinzie, R.A. (2003) Particle removal by coral reef communities: Picoplankton is a major source of nitrogen. Marine Ecology - Progress Series, Vol.257, pp. 13-23, ISSN 0171-8630

Riisgård, H.U. (1988) The ascidian pump-properties and energy-cost. Marine Ecology Progress Series, Vol.47, pp. 129-134, ISSN 0171-8630 
Robbins, I.J. (1984) Regulation of ingestion rate, at high suspended particulate concentrations, by some phleobranchiate ascidians. Journal of Experimental and Marine Biology and Ecology, Vol.82, pp. 1-10, ISSN 0022-0981

Sarà, G.; Lo Martire, M.; Buffa, G.; Mannino, A.M. \& Baalamenti, F. (2007) The fouling community as an indicator of fish farming impact in Mediterranean. Aquaculture Research, Vol.38, pp. 66-75, ISSN 1355-557X

Seaman, W. \& Jensen, A.C. (2000) Purpose and Practices of Artificial Reef Evaluation. In: Artificial Reef Evaluation: With Application to Natural Marine Habitats, W. Seaman (Ed.), 1-20, CRC Press, ISBN 084-939-061-3, Boca Raton, Florida, USA

Sebens, K.P.; Vandersall, K.S.; Savina, L.A. \& Graham, K.R. (1996) Zooplankton capture by two scleractinian corals, Madracis mirabilis and Monastrea cavernosa, in a field enclosure. Marine Biology, Vol.127, pp. 303-318, ISSN 0025-3162

Shin, P.K.S., Gao, Q.F. \& Cheung, S.G. (2011) Nutrient assimilation by organisms on artificial reefs in a fish culture (example of Hong Kong). In: Fish Farms, F. Aral (Ed.), InTech Publisher, ISBN 978-953-307-663-8, Croatia

Smaal, A.C. \& Vonck, A.P.M.A. (1997) Seasonal variation in C, N and P budgets and tissue composition of the mussel Mytilus edulis. Marine Ecology - Progress Series, Vol.153, pp. 167-179, ISSN 0171-8630

Smaal, A.C. \& Widdows, J. (1994) The Scope for Growth of Bivalves as an Integrated Response Parameter in Biological Monitoring. In: Biomonitoring of Coastal Waters and Estuaries, K. Kramer (Ed.), 247-268, CRC Press, ISBN 084-934-895-1, Boca Raton, Florida, USA

Smith, S.D.A. \& Rule, M.J. (2002) Artificial substrata in a shallow sublittoral habitat: Do they adequately represent natural habitats or the local species pool? Journal of Experimental and Marine Biology and Ecology, Vol.277, pp. 25-41, ISSN 0022-0981

Strickland, J.D.H. \& Parsons, T.R. (1977) A Practical Handbook of Seawater Analysis. Canadian Government Publishing Center, ISBN 066-011-596-4, Ottawa, Canada

Svane, I.B. \& Petersen, J.K. (2001) On the problems of epibioses, fouling and artificial reefs, a review. Marine Ecology, Vol.22, pp. 169-188, ISSN 0173-9565

Tsutsumi, H.; Srithongouthai, S.; Inoue, A.; Sato, A. \& Hama, D. (2006) Seasonal fluctuations in the flux of particulate organic matter discharged from net pens for fish farming. Fisheries Science, Vol.72, pp. 119-127, ISSN 0919-9268

Warren, C.E. \& Davis, G.E. (1967) Laboratory Studies on the Feeding Bioenergetics and Growth in Fish. In: The Biological Basis of Freshwater Fish Production, S.D. Gerking (Ed.), 175-214, Blackwell Scientific Publications, ISBN 063-200-256-5, Oxford, UK

Wilkinson, C. (1998) Status of Coral Reefs of the World. Australian Institute of Marine Science, ISBN 064232218 X, Townsville, Australia

Wong, W.H. \& Cheung, S.G. (2001) Feeding rates and scope for growth of Green mussels, Perna viridis (L.) and their relationship with food availability in Kat O, Hong Kong. Aquaculture, Vol.193, pp. 123-137, ISSN 0044-8486

Wotton, R.S. (1990) Particulate and Dissolved Organic Matter as Food. In: The Biology of Particles in Aquatic Systems, R.S. Wotton (Ed.), 213-261, CRC Press, ISBN 0-84935450-1, Boca Raton, Florida, USA 
Wu, R.S.S. (1995) The environmental impact of marine fish culture: Towards a sustainable future. Marine Pollution Bulletin, Vol.31, pp.159-166, ISSN 0025-326X

Zar, J.H. (1999) Biostatiscal Analysis (4th Ed.), Prentice-Hall, ISBN 817-758-582-7, New Jersey, USA 


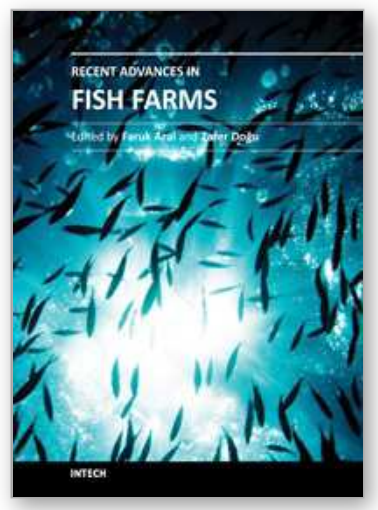

\author{
Recent Advances in Fish Farms \\ Edited by Dr. Faruk Aral
}

ISBN 978-953-307-759-8

Hard cover, 250 pages

Publisher InTech

Published online 21, November, 2011

Published in print edition November, 2011

The world keeps changing. There are always risks associated with change. To make careful risk assessment it is always needed to re-evaluate the information according to new findings in research. Scientific knowledge is essential in determining the strategy for fish farming. This information should be updated and brought into line with the required conditions of the farm. Therefore, books are one of the indispensable tools for following the results in research and sources to draw information from. The chapters in this book include photos and figures based on scientific literature. Each section is labeled with references for readers to understand, figures, tables and text. Another advantage of the book is the "systematic writing" style of each chapter. There are several existing scientific volumes that focus specially on fish farms. The book consists of twelve distinct chapters. A wide variety of scientists, researchers and other will benefit from this book.

\title{
How to reference
}

In order to correctly reference this scholarly work, feel free to copy and paste the following:

Paul K.S. Shin, Qinfeng Gao and Siu Gin Cheung (2011). Nutrient Assimilation by Organisms on Artificial Reefs in a Fish Culture (Example of Hong Kong), Recent Advances in Fish Farms, Dr. Faruk Aral (Ed.), ISBN: 978953-307-759-8, InTech, Available from: http://www.intechopen.com/books/recent-advances-in-fishfarms/nutrient-assimilation-by-organisms-on-artificial-reefs-in-a-fish-culture-example-of-hong-kong-

\section{INTECH}

open science | open minds

\author{
InTech Europe \\ University Campus STeP Ri \\ Slavka Krautzeka 83/A \\ 51000 Rijeka, Croatia \\ Phone: +385 (51) 770447 \\ Fax: +385 (51) 686166 \\ www.intechopen.com
}

\author{
InTech China \\ Unit 405, Office Block, Hotel Equatorial Shanghai \\ No.65, Yan An Road (West), Shanghai, 200040, China \\ 中国上海市延安西路65号上海国际贵都大饭店办公楼405单元 \\ Phone: +86-21-62489820 \\ Fax: +86-21-62489821
}


(C) 2011 The Author(s). Licensee IntechOpen. This is an open access article distributed under the terms of the Creative Commons Attribution 3.0 License, which permits unrestricted use, distribution, and reproduction in any medium, provided the original work is properly cited. 